\title{
Penggunaan Model PBL (Problem Based Learning) untuk Meningkatkan Kemampuan Pemecahan Masalah Matematika dan Self Efficacy Siswa
}

\author{
Suciyati $^{1)^{*},}$, Hardiansyah ${ }^{1)}$ \\ ${ }^{1)}$ STKIP Taman Siswa Bima \\ *suciyati.yasin@gmail.com
}

Abstrak: Permasalahan yang sering ditemukan oleh guru pada mata pelajaran matematika adalah rata-rata siswa belum mampu menyelesaikan soal pemecahan masalah dengan menggunakan langkah-langkah yang benar. Siswa masih belum mampu memahami masalah, menentukan dan melaksanakan perencanaan, maupun mengambil kesimpulan dengan benar. Hal ini dikarenakan siswa kurang berusaha dalam menyelesaikan soal. Kondisi tersebut disebabkan oleh siswa yang tidak yakin akan kemampuan dirinya sendiri (self efficacy) ditambah dengan penggunaan model pembelajaran yang masih konvensional. Penelitian yang digunakan adalah penelitian eksperimen dengan quasi experiment design, yaitu desain penelitian yang melibatkan dua kelompok (eksperimen dan kontrol). Quasi experiment design yang dipilih yaitu Nonrandomized Control Group Pretest-Postest Design. Populasi dalam penelitian ini adalah siswa SMP Negeri 3 Woha, dengan sampel penelitian menggunakan dua kelas yaitu satu kelas sebagai kelas eksperimen (VII.1) dan satu kelas sebagai kelas kontrol (VII.2). Berdasarkan beberapa hasil perhitungan dengan menggunakan SPSS 22.0, hasil penelitian menunjukkan bahwa pembelajaran dengan menggunakan model PBL berpengaruh dalam meningkatkan kemampuan pemecahan masalah matematika dan self efficcay siswa.

Kata Kunci: Problem Based Learning, Kemampuan Pemecahan Masalah, Self Efficacy

\section{Pendahuluan}

Matematika merupakan bagian integral dari umat manusia. Matematika tidak hanya melibatkan kumpulan angka, konsep, rumus, teorema, logika, gambar, dan langkah, tetapi angka-angka ini harus diingat untuk menyelesaikan masalah. Siswa perlu disadarkan betapa pentingnya matematika, karena pemikiran matematisnya perlu dikembangkan untuk mengamati dan menginterpretasikan dunia, kemampuan untuk memecahkan masalah matematika pun dibutuhkan dalam kehidupan sehari-hari, dan yang lebih penting, mereka harus memiliki sikap yang positif terhadap matematika (Zevenbergen et al., 2004).

Keseluruhan tujuan dalam pembelajaran matematika adalah pemecahan masalah, artinya kemampuan pemecahan masalah merupakan kemampuan dasar dalam belajar matematika (Sariningsih \& Purwasih, 2017). Pentingnya kemampuan pemecahan masalah merupakan syarat utama yang harus dimiliki oleh siswa. Hal ini menjadi dasar utama untuk meningkatkan kemampuan menguasai konsep lainnya. Maka upaya yang dapat dilakukan adalah dengan ditingkatkannya kemampuan siswa dalam menyelesaikan masalah matematika (Izzati, 2016).

Pemecahan masalah merupakan bagian dari kemampuan matematika, tetapi belum dikembangkan secara optimal di kalangan siswa (Eko et al., 2016). Pemecahan masalah dianggap sebagai aktivitas matematika yang sulit bagi guru yang mengajarnya dan siswa yang mempelajarinya (Sulastri et al., 2015). Dibarengi dengan kepercayaan guru yang mengganggap bahwa siswa mempunyai kemampuan dalam belajar dan kemampuan memecahkan masalah matematika yang sama (Vendiagrys \& Junaedi, 2015).

Permasalahan yang sering ditemukan oleh guru pada mata pelajaran matematika adalah rata-rata siswa belum mampu memecahkan soal pemecahan masalah dengan menggunakan langkah penyelesaian yang benar. Siswa masih belum mampu memahami masalah, menentukan dan melaksanakan perencanaan, maupun 
mengambil kesimpulan dengan benar. Kondisi tersebut disebabkan karena siswa kurang berusaha dalam memecahkan soal dan siswa yang tidak yakin akan kemampuan dirinya sendiri (self efficacy).

Permasalahan lain diperkuat oleh pendapat (Jumroh et al., 2018; Putri \& Santosa, 2015), dan Novferma (2016) yang menyatakan bahwa dalam pembelajaran matematika, self efficacy yang didapatkan oleh siswa masih rendah. Hal ini dapat dilihat dari perilaku menyerah siswa saat ditemuinya kesulitan dalam mempelajari atau memecahkan masalah. Perilaku ini juga dapat terjadi ketika siswa memperoleh informasi tentang materi yang sulit pada materi, sehingga siswa seringkali tidak mempunyai rasa percaya diri untuk mempelajarinya atau bahkan menyelesaikan masalah yang berkaitan dengan masalah tersebut (Subaidi, 2016). Padahal self-efficacy sangat diperlukan dalam memecahan masalah karena mempengaruhi kepercayaan diri siswa dalam setiap langkah pemecahan masalah yang diambil (Utami \& Wutsqa, 2017). Saat rasa self-efficacy siswa meningkat, diharapkan dapat berhasil menyelesaikan masalah matematika.

Maka permasalahan di atas dapat diatasi dengan menerapkan model PBL. Model pembelajaran PBL sangat cocok digunakan untuk pembelajaran matematika dalam usaha meningkatkan kemampuan pemecahan masalah karena memungkinkan siswa untuk berpartisipasi aktif dalam kegiatan mengajar (Olpado \& Heryani, 2017). Didukung juga dengan hasil penelitian Sumartini (2016) bahwa kemampuan pemecahan masalah matematika siswa yang memperoleh pembelajaran PBL lebih baik daripada siswa yang memperoleh pembelajaran konvensional.

Model pembelajaran PBL merupakan suatu pendekatan pembelajaran yang menggunakan latar belakang masalah aktual agar siswa dapat mempelajari keterampilan pemecahan masalah. Model PBL adalah model pembelajaran dengan menggunakan pendekatan pembelajaran kepada siswa pada masalah autentik sehingga pengetahuannya dapat tersusun sendiri, keterampilan dan kemampuan inkuiri dapat dikembangkan ke tingkat yang lebih tinggi, menjadikan siswa mandiri dan meningkatnya rasa percaya diri (Hosnan, 2014), sehingga memberikan kesempatan kepada siswa untuk meningkatkan self efficacy dalam dirinya.

\section{Metode}

Penelitian ini menggunakan penelitian eksperimen dengan quasi experiment design, yaitu desain penelitian yang melibatkan dua kelompok (eksperimen dan kontrol). Quasi experiment design yang dipilih pada penelitian kuantitatif ini adalah Nonrandomized Control Group Pretest-Postest Design. Desain penelitian kuantitatif dapat dilihat pada tabel 1 .

Tabel 1. Desain Penelitian Nonrandomized Control Group Pretest-Postest

\begin{tabular}{lccc}
\hline \multicolumn{1}{c}{ Kelas } & Pretest & Perlakuan & Postest \\
\hline Eksperimen & T1 & $\mathrm{X}$ & T2 \\
Kontrol & T1 & - & T2 \\
\hline
\end{tabular}

Keterangan: T1 : pretes kemampuan pemecahan masalah matematika dan angket self efficacy

$\mathrm{X}$ : penerapan model PBL pada pembelajaran

$\mathrm{T} 2$ : postes kemampuan pemecahan masalah matematika dan angket self efficacy

Penelitian dilaksanakan di SMP Negeri 3 Woha. Penelitian ini menggunakan populasi siswa SMP Negeri 3 Woha, dengan sampel penelitian menggunakan dua kelas yaitu satu kelas sebagai kelas eksperimen (VII.1) dan satu kelas sebagai kelas kontrol (VII.2). Adapun tahapan penelitian ditunjukkan pada Gambar 1.

\section{Uji Normalitas}

Pengujian kenormalan data menggunakan uji Kolmogorov-Smirnov dengan bantuan program SPSS 22.0. Kriteria pengujian hipotesis: $H_{0}$ diterima jika pada pada Test of Normality nilai signifikan $>5 \%$, sebaliknya $H_{0}$ ditolak.

\section{Uji Homogenitas}

Uji homogenitas dibuktikan dengan bantuan program SPSS 22.0 melalui uji Levene. Kriteria pengujian hipotesis: $H_{0}$ diterima jika pada tabel Levene Statistic nilai sig > 5\%, sebaliknya $H_{0}$ ditolak. 


\section{Uji Hipotesis}

Perhitungan uji hipotesis dalam penelitian ini menggunakan program SPSS 22.0 melalui uji Independent Sample T-Test. Kriteria pengujian hipotesis: $H_{0}$ diterima jika nilai sig $>5 \%$, sebaliknya $H_{0}$ ditolak.

Sebelum penelitian:

1. Pelaksanaan observasi

2. Membuat instrument penelitian
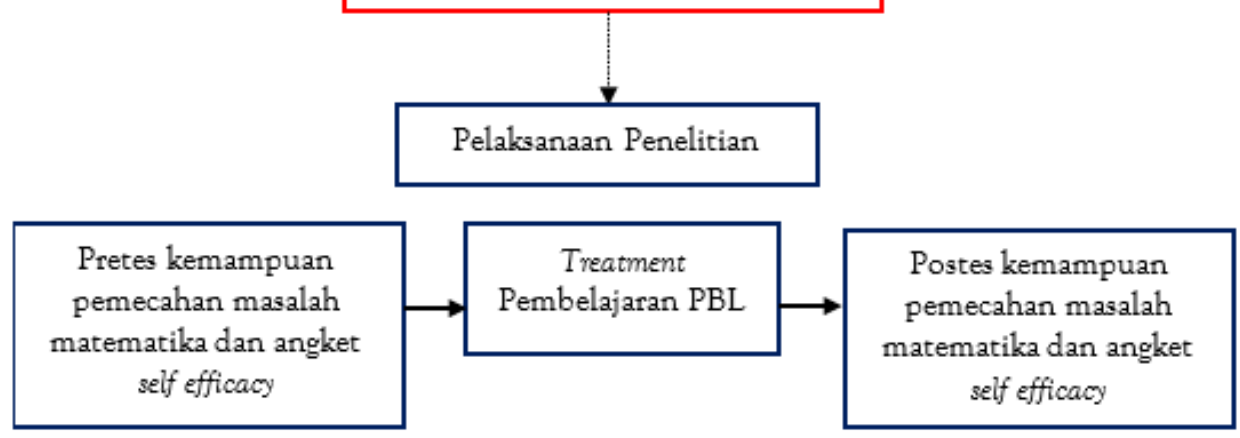

Gambar 1. Tahapan Penelitian

\section{Hasil dan Pembahasan}

Penelitian ini dilakukan di SMP Negeri 3 Woha di kelas VII.1 (kelas kontrol) dan kelas VII.2 (kelas eksperimen). Kelas VII.1 dan VII.2 masing-masing terdiri dari 30 siswa. Kedua kelas memiliki kemampuan pemecahan matematika yang sama.

Sebelum diterapkan model PBL terlebih dahulu dilakukan uji normalitas. Uji normalitas digunakan untuk mengetahui apakah data awal yang diteliti berdistribusi normal atau tidak. Uji normalitas diambil dari nilai pretest dengan menggunakan uji Kolmogorof Smirnov dengan bantuan SPSS 22.0. Kriteria pengujian yang digunakan adalah terima $H_{0}$ jika pada pada Test of Normality nilai sig $>5 \%$.

Berdasarkan pengujian menggunakan SPSS 22.0 diperoleh nilai sig $=0,200=20 \%>5 \%$, dan sig $=0,167$ $=16,7 \%>5 \%$ berarti $H_{0}$ diterima. Artinya data nilai tes awal (pretest) kemampuan pemecahan masalah matematika kelas ekperimen dan kontrol berasal dari populasi berdistribusi normal.

Setelah dilakukan uji normalitas dan diperoleh bahwa data berdistribusi normal, selanjutnya dilakukan uji homogenitas. Uji homogenitas dilakukan untuk mengetahui data awal (pretest) pada kelas eksperimen dan kelas kontrol memiliki varians yang sama. Uji homogenitas menggunakan uji Levene dengan bantuan SPSS 22.0. Kriteria pengujian yang digunakan adalah terima $H_{0}$ jika pada Tabel Levene Statistic nilai sig $>5 \%$.

Hasil pengujian dengan menggunakan SPSS 2.0 diperoleh nilai sig $=0,759=75,9 \%>5 \%$, maka $H_{0}$ diterima. Artinya kedua kelas, eksperimen dan kontrol mempunyai varians yang sama (homogen).

Selanjutnya dilakukan uji hipotesis untuk mengetahui ada atau tidaknya perbedaan pemecahan masalah dan self efficacy yang signifikan antara siswa yang diajarkan dengan model PBL dengan siswa yang diajarkan dengan model konvensional. Data kemampuan pemecahan masalah diambil dari hasil postest siswa sedangkan data self efficacy diperoleh melalui angket yang diberikan pada akhir treatment pada kedua kelas yaitu kelas eksperimen dan kelas kontrol. Perhitungan uji hipotesis menggunakan program SPSS 22.0 melalui uji Independent Sample T-Test.

Pada output hasil pengujian dengan menggunakan uji Independent Samples Test terlihat bahwa t hitung untuk nilai postest dengan Equal variances not assumed adalah 4,002 dengan probabilitas 0,000. Karena 0,000 < 0,025, maka $H_{0}$ ditolak. Sedangkan output Tabel 6 juga menggunakan uji Independent Samples Test menunjukkan bahwa t hitung untuk nilai self efficacy dengan Equal variances not assumed adalah 2,727 dengan probabilitas 0,009 untuk uji dua sisi, probabilitas menjadi 0,009/2=0,0045. Karena 0,0045<0,025, maka $H_{0}$ ditolak. Hal ini menunjukkan ada perbedaan signifikan antara siswa yang diajarkan dengan model PBL dengan siswa yang diajarkan dengan model konvensional dilihat dari kemampuan pemecahan masalah dan self efficacy. 
Berdasarkan uraian di atas, karena ketiga aspek keefektifan terpenuhi maka dapat disimpulkan bahwa pembelajaran dengan menggunakan model PBL dapat secara efektif meningkatkan kemampuan pemecahan matematika dan self efficacy siswa. Sejalan dengan hasil penelitian yang dilakukan oleh Mariani et al., (2014) dan (Bilgin et al., 2009) yang menyatakan bahwa pembelajaran PBL dapat meningkatkan motivasi siswa untuk memecahkan masalah dunia nyata dan menjadikan pembelajaran lebih efektif. Penggunaan PBL untuk pembelajaran akan memungkinkan siswa mengetahui informasi tentang masalah, kemudian siswa akan menemukan informasi yang dibutuhkan untuk menyelesaikan masalah dan strategi apa yang dapat digunakan untuk memudahkan dalam menyelesaikan masalah tersebut.

Model pembelajaran PBL merupakan salah satu model pembelajaran yang dapat menjadikan siswa tertantang untuk aktif belajar dan bekerja sama secara berpasangan atau berkelompok untuk memperoleh pengetahuan dan keterampilan dengan menemukan masalah dan membangun pemahaman, dan mencari cara lain untuk menyelesaikan masalah untuk memperoleh pengetahuan dan keterampilan (Yunianti et al., 2016). Dengan diterapkannya model PBL di kelas, siswa menjadi terbantu dengan menjadi lebih mengenal materi ajar, mendorong mereka untuk memecahkan masalah, memungkinkan siswa menunjukkan sikap dan kemampuan yang baik dalam proses dan hasil pembelajaran, serta meningkatkan self-efficacy siswa (Gunantara et al., 2014, Cheriani et al., 2015, Masitoh \& Fitriyani, 2018). Karena self-efficacy itu sendiri merupakan kemampuan siswa dalam memecahkan masalah khususnya yang berkaitan dengan matematika.

\section{Simpulan}

Hasil uji dengan menggunakan SPSS 22.0 didapatkan nilai t hitung untuk nilai postest atau kemampuan pemecahan masalah dengan Equal variances not assumed adalah 4,002 dengan probabilitas 0,000. Sedangkan nilai thitung untuk nilai angket self efficacy dengan Equal variances not assumed adalah 2,727 dengan probabilitas 0,009 untuk uji dua sisi, probabilitas menjadi $0,009 / 2=0,0045$. Karena $0,000<0,025$ dan 0,0045 $<0,025$, maka $H_{0}$ ditolak. Hal ini menunjukkan ada perbedaan signifikan antara siswa yang diajarkan dengan model PBL dengan siswa yang diajarkan dengan model konvensional dilihat dari kemampuan pemecahan masalah dan self efficacy.

\section{Ucapan Terima Kasih}

Ucapan terimakasih penulis sampaikan kepada Kemenristekdikti yang telah mendanai penelitian ini pada skim PDP (Penelitia Dosen Pemula) tahun anggaran 2020. Ucapan terimkasih juga disampaikan kepada Ketua STKIP Taman Siswa Bima, Dewan Pembina dan Yayasan beserta LPPM, Kepala SMP Negeri 3 Woha beserta guru mata pelajaran matematika yang sudah memberikan kesempatan penulis untuk melaksanakan kegiatan penelitian.

\section{Daftar Pustaka}

Bilgin, I., Şenocak, E., \& Sözbilir, M. (2009). The effects of problem-based learning instruction on university students' performance of conceptual and quantitative problems in gas concepts. Eurasia Journal of Mathematics, Science and Technology Education, 5(2), 153-164. https://doi.org/10.12973/ejmste/75267

Cheriani, Mahmud, A., Tahmir, S., Manda, D., \& Dirawan, G. D. (2015). Problem-based learning-buginese cultural knowledge model-case study: Teaching mathematics at junior high school. International Education Studies, 8(4), 104-110. https://doi.org/10.5539/ies.v8n4p104

Eko, B., Riau, S., Junaedi, I., \& Artikel, I. (2016). Analisis Kemampuan Pemecahan Masalah Matematik Siswa Kelas Vii Berdasarkan Gaya Belajar Pada Pembelajaran Pbl. Unnes Journal of Mathematics Education Research, 5(2), 166-177.

Gunantara, Suarjana, \& Riastini. (2014). Penerapan Strategi Pembelajaran Problem Based Learning Untuk Meningkatkan Kemampuan Pemecahahan Masalah Matematis Siswa Kelas IV. Jurnal Mimbar PGSD Universitas Pendidikan Ganesha, 2(1). https://doi.org/10.15294/kreano.v10i2.19671

Izzati, N. (2016). Meningkatkan Kemampuan Mahasiswa dalam Menyusun RPP melalui Penerapan Model Pembelajaran Berbasis Portofolio. Jurnal Euclid, 4(1), 659-674.

Jumroh, J., Mulbasari, A. S., \& Fitriasari, P. (2018). Self-Efficacy Siswa Dalam Pembelajaran Matematika Dengan 
Strategi Inquiry Based Learning Di Kelas Vii Smp Palembang. Jurnal Pendidikan Matematika RAFA, 4(1), 29-42. https://doi.org/10.19109/jpmrafa.v4i1.2480

Mariani, S., Wardono, \& Kusumawardani, E. D. (2014). Peningkatan Kemampuan Pemecahan Masalah Matematis Siswa melalui Pembelajaran Berbasis Masalah. Mosharafa: Jurnal Pendidikan Matematika, 2(8), 148-158. https://doi.org/10.31980/mosharafa.v5i2.270

Masitoh, L. F., \& Fitriyani, H. (2018). Improving students' mathematics self-efficacy through problem based learning. Malikussaleh Journal of Mathematics Learning (MJML), 1(1), 26. https://doi.org/10.29103/mjml.v1i1.679

Novferma, N. (2016). Analisis Kesulitan Dan Self-Efficacy Siswa Smp Dalam Pemecahan Masalah Matematika Berbentuk Soal Cerita. Jurnal Riset Pendidikan Matematika, 3(1), 76. https://doi.org/10.21831/jrpm.v3i1.10403

Olpado, S. U., \& Heryani, Y. (2017). Korelasi antara motivasi belajar dengan kemampuan pemecahan masalah matematik peserta didik menggunakan model problem based learning (PBL). Jurnal Penelitian Pendidikan Dan Pengajaran Matematika, 3(1), 63-70.

Putri, R. I., \& Santosa, R. H. (2015). Keefektifan Strategi React Ditinjau Dari Prestasi Belajar, Kemampuan Penyelesaian Masalah, Koneksi Matematis, Self Efficacy. Jurnal Riset Pendidikan Matematika, 2(2), 262. https://doi.org/10.21831/jrpm.v2i2.7345

Sariningsih, R., \& Purwasih, R. (2017). Pembelajaran Problem Based Learning Untuk Meningkatkan Kemampuan Pemecahan Masalah Matematis Dan Self Efficacy Mahasiswa Calon Guru. JNPM (Jurnal Nasional Pendidikan Matematika), 1(1), 163. https://doi.org/10.33603/jnpm.v1i1.275

Subaidi, A. (2016). Self-Efficacy Siswa Dalam Pemecahan Masalah Matematika. Jurnal Eigma. Universitas Madura, $1(2), 64-68$.

Sulastri, Mariani, \& Mashuri. (2015). Kreano. Kreano Ju rn a l M a t e ma ti k a Kre a t if - I n o va t i F, 6(1), $26-32$.

Utami, R. W., \& Wutsqa, D. U. (2017). Analisis kemampuan pemecahan masalah matematika dan self-efficacy siswa SMP negeri di Kabupaten Ciamis. Jurnal Riset Pendidikan Matematika, 4(2), 166. https://doi.org/10.21831/jrpm.v4i2.14897

Vendiagrys, L., \& Junaedi, I. (2015). Analisis Kemampuan Pemecahan Masalah Matematika Soal Setipe Timss Berdasarkan Gaya Kognitif Siswa Pada Pembelajaran Model Problem Based Learning. Unnes Journal of Research Mathematics Education, 4(1), 34-41.

Yunianti, E., Jaeng, M., \& Mustamin. (2016). Pengaruh Model Pembelajaran Dan Self-Efficacy Terhadap Hasil Belajar Matematika Siswa Sma Negeri 1 Parigi. EJurnal Mitra Sains, 4(1), 8-19.

Zevenbergen, R., Dole, S., \& Wright, R. J. (2004). Teaching Mathematics in Primary School. Allen \& Unwin. 